\title{
ANALISIS KEPATUHAN PEMBAYARAN PAJAK PENGHASILAN PASAL 23 TOKO KELONTONG DI DI DESA BEJI
}

\author{
Oleh : Yulia Aroningtias, Defilatifah, Feni Setyorini \\ Fakultas Ekonomi,Universitas Tulungagung
}

\begin{abstract}
The purpose of this study was to determine the calculation, deposit and reporting of Corporate Income Tax carried out at a grocery store in Beji Village and how the perception of grocery store owners towards the existence of a modern market. Knowing the impact of the existence of a modern market on tax payment compliance in the grocery store business. To achieve the objectives in this study used a qualitative type of research with interview survey methods. Qualitative analysis uses data reduction, data presentation, and drawing conclusions. The results showed. The existence of modern minimarkets on grocery stores has a negative impact on turnover, income and the number of customers so that the payment of corporate income tax that should be paid is ignored by the grocery store business owner.
\end{abstract}

\section{Keyword: Corporate income tax, Minimarkets, Grocery store}

\begin{abstract}
ABSTRAK
Tujuan dari penelitian ini dilakukan untuk mengetahui perhitungan, penyetoran dan pelaporan Pajak Penghasilan Badan yang dilakukan di toko kelontong di Desa Beji dan bagaimana persepsi pemilik toko kelontong terhadap keberadaan pasar modern. Mengetahui dampak keberadaan pasar modern terhadap kepatuhan pembayaran pajak pada usaha toko kelontong.. Untuk mencapai tujuan dalam penelitian ini mengunakan jenis penelitian kualitatif dengan metode survei wawancara. Analisis Kualitatif menggunakan reduksi data, penyajian data, dan penarikan kesimpulan. Hasil penelitian menunjukkan. Keberadaan Minimarket modern terhadap toko kelontong berdampak negatif pada omzet, pendapatan dan jumlah pelanggan sehingga pembayaran pajak penghasilan badan yang seharusnya dibayarkan diabaikan oleh pemilik usaha toko kelontong.
\end{abstract}

Kata kunci: Pajak penghasilan badan, minimarket, toko kelontong. 


\section{PENDAHULUAN}

Toko kelontong adalah suatu toko kecil yang biasanya mudah diakses umum dan bersifat lokal. Toko semacam ini biasanyaa berlokasi di jalan yang ramai. Toko kelontong sering ditemukan di lokasi perumahan padat baik dikota maupun di desa. Saat ini dapat dirasa bahwa toko modern seperti minimarket telah menjamur dimana mana baik dikota maupun didesa, dimana kehadiran toko modern tersebut membuat toko kelontong semakin tergeser,manajemen dan penawaran penawaran menarik dari toko moderm atau minimarket membuat masyarakat lebih tertarik belanja di toko meren atau minimarket,selain itu faktor pelayanan yang ramah dan tempat yang nyaman dari toko modern menjadi pilihan tempat yang menggiurkan untuk berbelanja, hal terebut berbanding terbalik dengan keadaan toko kelontong yang pelayanannya terkadang kurang ramah serta tempat yang sempit dan tidak tertata rapi. Faktor faktor yang membuat bisbis ritel di Indonesia menjamur adalah faktor peningkatan produk konsumen makanan dan minuman. Diperkirakan pertumbuhan konsumsi makanan Indonesia secara keseluruhan sangat kuat, yang telah dan akan terus didukung oleh pertumbuhan ekonomi yang kuat di negara ini dengan kenaikan pendapatan per kapita yang sepadan. Faktor kedua bagi peningkatan bisnis ritel di Indonesia adalah faktor peningkatan belanja produk konsumen elektronik Faktor ketiga bagi peningkatan bisnis ritel di Indonesia adalah peningkatan populasi Indonesia yang sedemikain pesat Faktor ke empat dalam peningkatan bisnis ritel di Indonesia adalah peningkatan minimarket di seluruh pelosok Indonesia(Sudirga, 2017). Akibat munculnya toko modern membuat toko kelontong mulai kehilangan pelanggannya sehingga membuat omzet penjualan toko kelontong menurun drastis,

Dampak dari banyaknya minimarket yang muncul membuat toko kelontong menjadi sepi sehingga pendapatannya menurun. Penelitian ini bertujuan untuk mengetahui pengaruh penurunan omzet terhadap ketaatan pembayaran Pajak Penghasilan Badan. Penelitian ini merupakan penelitian deskriptif kualitatif dengan menggunakan data primer yaitu dengan wawancara kepada para pemilik toko kelontong di Desa Beji, Kecamatan Boyolangu,Kabupaten Tulungagung. Populasi yang digunakan dalam penelitian ini adalah pemilik toko kelontong di Desa Beji dengan jumlah sampel 10 toko. Hasil penelitian ini menggambarkan adanya perubahan penurunan tingkat omzet, keuntungan, dan jumlah pengunjung toko akibat dari munculnya minimarket di sekitar 
tempat berdirinya toko kelontong. Pembahasan yang menarik dikarenakan pertumbuhan minimarket bahkan sampai ke daerah pedesaan dinilai sangat cepat, tentu hal ini berhubungan dengan kelangsungan usaha pedagang kelontong disekitarnya, karena minimarket dan toko kelontong sama-sama menjual produk yang sama, namun tidak selengkap dan sebesar di minimarket.

Pajak merupakan sumber penerimaan Negara disamping penerimaan dari sumber migas dan non migas. Penghasilan negara adalah berasal dari rakyatnya melalui pungutan pajak, dan atau dari hasil kekayaan alam yang ada dalam negara itu, Penghasilan itu untuk membiayai kepentingan umum yang akhirnya juga mencakup kepentingan pribadi individu seperti kesehatan masyarakat, pendidikan, kesejahteraan dan sebagainya. Jadi, dimana ada kepentingan masyarakat, disana timbul pungutan pajak sehingga pajak adalah senyawa dengan kepentingan umum (Ratnawati \& Rachmad Gesah Mukti Prabowo, 2019) . pajak muncul Ketika objek pajak bertemu dengan subjek pajak dimana objek pajak merupakan penghasilan dan subjek pajak adalah orang atau badan atau organisasi. Ketika objek dan subjek bertemu maka muncul kewajiban membayar pajak. Pajak PPh Badan merupakan pemajakan bagi badan atas penghasilan yang diperolehnya(Barata, 2011). Adapun yang menjadi ukuran dalam penerimaan pajak penghasilan badan adalah jumlah pajak penghasilan badan yang disetor, tercapainya target pajak penghasilan badan, kekurangan atau kelebihan pembayaran pajak penghasilan badan (Nurani, 2018; Wandira, 2017)

1) Jumlah pajak penghasilan badan yang disetor adalah seluruh penerimaan negara yang bersumber dari pajak penghasilan yang telah dilakukan oleh wajib pajak.

2) Tercapainya target pajak penghasilan badan yaitu suatu kondisi yang menggambarkan tercapainya rencana penerimaan pajak penghasilan.

3) Kekurangan atau kelebihan pembayaran pajak penghasilan badan yaitu selisih antara setoran pajak penghasilan yang telah dilakukan oleh wajib pajak penghasilan yang seharusnya terutang.

Penelitian ini dilakukan untuk megetahui mengenai kesadaran pembayaran pajak penghasilan badan atas penghasilan dari usaha toko kelontong yang berada di Desa Beji,kecamatan Boyolangu,Kabupaten Tulungagung,selain itu tujuan dari penelitian ini 
untuk mengetahui pengaruh perubahan omzet penjualan terhadap kepatuhan pembayaran pajak penghasilan pasal 23.

\section{LANDASAN TEORI}

\section{Pengertian Pajak}

Menurut Djajadiningrat, pajak adalah kewajiban yang dipaksakan untuk diserahkan kepada negara atas kejadian, perbuatan, atau kedudukan, bukan sebagai hukuman, tanpa mendapat jasa timbal balik langsung demi kesejahteraan umum (Resmi, 2017)

Pajak memiliki beberapa fungsi diantaranya adalah untuk mengatur perekonomian, mengganggarkan keuangan negara, stabiltias ekonomi, dan redistribusi pendapatan. Sistem pemungutan pajak yang diatur oleh pemerintah dengan beberapa cara, yaitu wajib pajak memperhitungkan sendiri pajak yang harus disetor ke kas negara atau biasa disebut Self Assessment System, kemudian terdapat juga proses pemungutan pajak yang besaran pajaknya ditentukan oleh fiskus atau dikenal dengan Official Assessment System, serta terdapat proses pemungutan pajak yang dilakukan oleh pihak ketiga atau disebut denganWitholding Tax System.

\section{Pengertian Pajak Penghasilan}

Pajak penghasilan biasa disebut dengan Pajak Penghasilan Pasal 25 atau PPh 25 adalah pajak yang dikenakan untuk orang pribadi, perusahaan atau badan hukum lainnya atas penghasilan yang didapat.

Menurut (Halim et al., 2014) Pajak Penghasilan Pasal 21 yaitu Pajak atas penghasilan sehubungan dengan pekerjaan, jasa, atau kegiatan dengan nama dan dalam bentuk apapun yang diterima atau diperoleh Wajib Pajak orang pribadi dalam negeri sebagaimana diatur dalam Pasal 21 Undang-Undang Pajak Penghasilan

Sedangkan menurut (Sutanto, 2014) Pajak Penghasilan adalah pajak atas penghasilan berupa gaji, upah, honorarium, tunjangan, dan pembayaran lain dengan nama dan dalam bentuk apapun sehubungan dengan pekerjaan atau jabatan, jasa, atau kegiatan yang dilakukan oleh orang pribadi. Subjek pajak dalam negeri, sebagaimana dimaksud dalam Pasal 21 Undang-Undang Pajak Penghasilan 
Dari pengertian di atas dapat disimpulkan bahwa pajak penghasilan adalah pajak yang harus dibayarkan atas pekerjaaan,jasa dan penghasilan lainnya yang dibayarkan kepada negara untuk membiayai pengeluaran negara.

\section{Cara Menghitung Pajak Penghasilan}

Bagi para wajib pajak yang baru saja memulai suatu usaha UKM, proses perhitungan pajak bisa dilakukan dengan cara sebagai berikut

a) Hitung penghasilan bruto. Di akhir periode akuntansi bisnis, pasti akan ada laporan keuangan yang menyatakan berapa besar penghasilan bisnis laporan keuangan ini atau catatan transaksi yang telah dilakukan dalam bisnis untuk bisa menyusun tahap ini.

b) Hitung penghasilan netto. Setelah memiliki penghasilan bruto, maka Anda bisa menghitung penghasilan bersih perusahaan Anda. tahap ini sama seperti tahap pembuatan laporan keuangan. Membuat laba rugi dan neraca keuangan untuk memperjelas kondisi keuangan perusahaan dalam satu periode.

c) Hitung Penghasilan Kena Pajak (PKP) Cara menghitung PKP adalah penghasilan bersih selama satu periode akuntansi dikurangi dengan penghasilan tidak kena pajak (PTKP).

d) Hitung PPh yang harus dibayarkan.Setelah mendapatkan nilai PKP, maka Anda hanya perlu mengalikan dengan tarif Pajak PPh dalam setahun.

Sedangkan menurut (Harjo, 2013) Berikut dijelaskan 3 (tiga) metode perhitungan :

1. Gross Method

Dalam metode ini seluruh Pajak Penghasilan Pasal 21 menjadi tanggungan pekerja/pegawai, sehingga penghasilan yang diterima pekerja/pegawai telah dipotong dengan PPh Pasal 21.

2. Nett Method

Dalam metode ini seluruh Pajak Penghasilan Pasal 21 menjadi tanggungan pemberi kerja/perusahaan, sehingga penghasilan yang diterima pekerja utuh dan tidak dipotong dengan PPh Pasal 21. Metode ini mencatat tanggungan PPh Pasal 21 sebagai biaya operasional secara komersial namun beban ini tidak dapat menjadi pengurang 
penghasilan bruto dalam menentukan Penghasilan Kena Pajak pemberi kerja dalam laba rugi fiskalnya, karena beban ini dianggap sebagai kenikmatan.

3. Gross Method

Dalam metode ini pemberi kerja memberikan tunjangan Pajak Penghasilan Pasal 21 kepada pekerja/pegawai yang nilainya sama dengan PPh Pasal 21 yang dipotong. Metode ini mencatat tanggungan PPh Pasal 21 sebagai biaya operasional fiskal dan dapat menjadi pengurang penghasilan bruto dalam rangka menentukan Penghasilan Kena Pajak pemberi kerja karena PPh Pasal 21 tersebut diberikan dalam bentuk tunjangan yang menambah penghasilan pekerja.

\section{Pengertian Pajak Penghasilan Badan}

Pajak penghasilan badan merupakan pemungutan resmi yang dikenakan pada setiap tambahan kemampuan ekonomis yang diterima oleh Wajib Pajak dari suatu badan usaha, baik yang berasal dari dalam negeri maupun luar negeri dalam bentuk dan nama apapun (Vindasari, 2020)

Pajak PPh Badan merupakan pemajakan bagi badan atas penghasilan yang diperolehnya (Barata, 2011) penerimaan pajak adalah sumber penerimaan yang dapat diperoleh secara terus menerus dan dapat dikembangkan secara optimal sesuai kebutuhan pemerintah serta kondisi masyaraka(Hutagaol, 2007).

Dari beberapa pengertian diatas dapat dikatakan bahwa pajak penghasilan badan adalah pajak yang dikenakan atas penghasilan dari suatu usaha baik usaha dari dalam negri maupun luar negeri.

\section{Cara Menghitung Pajak Penghasilan Badan}

Dalam Undang-Undang No. 36 Tahun 2008, untuk menghitung pajak penghasilan badan bisa dilakukan dengan beberapa opsi. Opsi yang pertama, yaitu memilih perhitungan apabila badan usaha tersebut tidak memilki pembukuan atau pencatatan, penghasilan kena pajak yaitu pemdapatan bruto dikalikan dengan tarif pajak menggunakan Norma Perhitungan Penghasilan Neto (NPPN). Kemudian opsi kedua, yaitu apabila badan usaha tersebut telah melakukan pembukuan dan pencatatan lengkap maka badan usaha tersebut wajib menghitung penghasilan kena pajaknya berdasarkan pendapatan neto fiskal dikalikan tarif pajak penghasilan badan. Untuk yang memilih 
kedua opsi tersebut apabila pendapatan brutonya antara Rp 4,8 miliar s/d Rp 50 miliar maka akan mendapatakan fasilitas pengurangan tarif sebesar 25\% dan apabila peredaran brutonya melebihi Rp 50 miliar maka tidak akan dikenakan pengurangan tarif dan tarif pajaknya tunggal sebesar 25\%. Berbeda dengan opsi yang terakhir yaitu, wajib pajak badan yang memiliki pendapatan bruto dibawah $\mathrm{Rp}$ 4,8 miliar berhak mendapatkan tarif pajak final sebesar 0,5\% sesuai dengan PP No. 46 Tahun 2013.

\section{Toko Kelontong dan Minimarket}

Menurut Wikipedia toko kelontong adalah toko kecil yang menjual segala macam barang dan makanan,yang umumnya mudah diakses umum atau bersifat. Toko kelontong adalah toko kecil yang menjual kebutuhan sehari hari dan terletak di dekat perumahan atau lokasi umum lainnya agar supaya bisa lebih mudah diakses banyak orang.

Kata Retail berasal dari bahasa Perancis Ritellier, yang berarti memotong atau memecah sesuatu.(Utami, 2010). Retail bisa disebut juga dengan penjualan barang secara eceran, bisnis retail merupakan suatu bisnis menjual produk dan jasa pelayanan yang telah diberi nilai tambah untuk memenuhi kebutuhan pribadi, keluarga atau pengguna akhir lainnya (Sunyoto, 2015). Dengan demikian dapat dikatakan bisnis ritel adalah keseluruhan aktivitas bisnis yang menyangkut penjualan barang atau jasa, atau barang dan jasa, yang dilakukan oleh perusahaan atau institusi bisnis secara langsung kepada konsumen akhir

\section{perbedaan toko kelontong dan minimarket}

Perbedaan antara toko kelontong dengan minimarket terletak pada beberapa aspek, seperti sistem pembayaran, sistem pembelian, variasi produk, tempat, harga, pelayanan, promo dan penawaran.

Sistem pembayaran pada minimarket menerapkan sebuah sistem mesin kasir point of sale untuk penjualan nya sehingga pembayaran produk bisa lebih cepat dan rinci karena menggunakan mesin barcode scanner yang bisa otomatis terhitung dan tercetak nota,sedangkan pada toko kelontong sistem pembayaran masih dilakukan secara manual,apabila ada pembeli dengan jumlah produk yang banya seringkali pemilik toko kelontong kesusahan dalam menghitungnya dan nota yang disediakan juga masih manual atau tulis tangan. 
Sistem pembelian pada minimarket menerapkan sistem swalayan, dimana konsumen mengambil sendiri barang yang dibutuhkan dari rak rak dan membayarnya di meja mesin kasir,sedangkan toko kelontong tidak menerapkan sistem tersebut,pada toko kelontong ada beberapa produk yang bisa di ambil sendiri oleh konsumen dan ada beberapa produk yang diambilkan oleh pemilik toko kelontong.

Variasi produk pada toko kelontong terbilang lebih terbatas dibandingkan dengan minimarket yang menjual berbagai produk yang lebih bervariasi

Dilihat dari segi tempat minimarket memiliki tempat yang lebih luas dan bersih,produk pada minimarket umumnya tertata rapi karena luasnya minimarket tersebut, selin itu terdapat fasilitas seprti AC,tempat duduk dan meja yang dapat digunakan konsumen untuk bersantai. Berbeda dengan toko kelontong yang terbilang cukup sempit dan tak jarang penataan produknya terlihat kurang rapi dan saling bertumpuk antara produk satu dengan produk lainnya.

Minimarket juga sering mengadakan promo promo menarik berupa diskon atau potongan harga, beli 2 gratis 1 dan lain lain. Hal ini sangat terbanding terbalik toko kelontong yang tidak pernah menawarkan promo promo menarik seperti halnya di minimarket.

Pelayanan dari minimarket dinilai lebih bagus dan ramah,terlihat dari beberapa minimarket yang memberikan sambutan ramah Ketika calon konsumen datang,selain itu minimarket juga menyediakan aplikasi atau web yang bisa digunakan konsumen jika ingin menggunakan pelayanan jasa antar produk ke rumah.

Dilihat dari segi harga pada minimarket hampir sama dengan toko kelontong, namun pada toko kelontong bisa menyepakati pemberian "BON" atau menghutang,sehingga bisa memudahkan konsumen apabila sedang dalam keadaan finansial yang kurang baik.

Berbagai persoalan utama dalam industri ritel ini terletak pada ketidakmampuan pelaku usaha toko kelontong untuk bersaing dengan pelaku usaha ritel modern, baik dari aspek keuangan maupun manajemen usaha. Kemampuan permodalan kedua belah pihak sangat jauh berbeda sekali sehingga value creation yang dihasilkan pelaku usaha ritel modern sama sekali tidak dapat dilakukan oleh pelaku usaha toko kelontong (Spasial et al., 2013). 


\section{METODE PENELITIAN}

\section{Jenis Penelitian}

Jenis penelitian deskriptif kualitatif merupakan sebuah metode penelitian yang memanfaatkan data kualitatif dan dijabarkan sejara deskriptif. Jenis penelitian deskriptif kualitatif kerap digunakan untuk menganalisis kejadian, fenomena, atau keadaan secara sosial.jenis penelitian deskriptif kualitatif menafsirkan dan menguraikan data yang ada bersamaan dengan situasi yang sedang terjadi. Penelitian ini juga mengungkapkan sikap, pertentangan, hubungan serta pandangan yang terjadi pada sebuah lingkup responden.

\section{Populasi dan Sampel}

Populasi adalah wilayah generalisasi yang terdiri atas objek atau subjek yang mempunyai kualitas dan karakteristik tertentu yang ditetapkan oleh peneliti untuk dipelajari dan kemudian ditarik kesimpulannya (Sugiyono, 2010). Populasi dalam penelitian ini adalah seluruh toko kelontong di Desa Beji,Kecamatan Boyolangu Kabupaten Tulungagung sejumlah 21 toko kelontong.

Sampel adalah cara pengumpulan data apabila yang diselidiki adalah elemen sampel dari suatu populasi (Supranto, 2008). Sampel dalam penelitian ini adalah beberapa toko kelontong di Desa Beji,Kecamatan Boyolangu Kabupaten Tulungagung sejumlah 10 toko kelontong.

\section{Tempat dan Waktu Penelitian}

Penelitian ini dilakukan di Desa Beji Kecamatan Boyolangu Kabupaten Tulungagung. Penelitian ini dilakukan pada bulan Maret - Mei 2021.

\section{Prosedur Penelitian}

1. Melakukan survey awal Toko Kelontong di Desa Beji

2. Mengumpulkan data yang diperlukan

3. Mengelola data yang telah dikumpulkan

4. Menarik kesimpulan dan saran 


\section{Objek Penelitian}

Objek penelitian sasaran untyk mendapatkan tujuan mengenai suatu hal yang akan dibuktikan secara objektif. Dalam objek penelitian ini yang digunakan kepatuan wajib pajak,,metode pembayaran pajak.

\section{Metode Pengumpulan Data}

Metode dalam mengumpulkan data yang kami gunakan dalam penelitian ini adalah dengan cara melakukan wawancara dengan narasumber yaitu pemilik toko kelontong di Desa Beji. Metode analisis data yang digunakan dalam penelitian adalah analisis dekriptif kualitatif. Dalam penelitian ini bertujuan untuk menganalisis pajak penghasilan orang pribadi yaitu kepatuhan wajib pajak

\section{Sumber Data}

Sumber data yang digunakan dalam penelitian ini adalah data primer. Data primer, merupakan sumber data penelitian yang diperoleh secara langsung dari sumber asli atau tidak melalui media perantara.

\section{PEMBAHASAN}

Indonesia yang termasuk sebagai negara berkembang dengan jumlah penduduk yang banyak, dinilai sebagai salah satu ladang usaha para investor dalam mengembangkan usaha minimarket. Industri ritel di Indonesia saat ini semakin berkembang dengan semakin banyaknya pembangunan gerai-gerai baru di berbagai tempat. Kegairahan para pengusaha ritel untuk berlomba-lomba menanamkan investasi dalam pembangunan gerai-gerai baru tidaklah sulit untuk dipahami. Dengan pertumbuhan ekonomi rata-rata di atas 3\% sejak tahun 2000 dan makin terkendalinya laju inflasi, bisa menjadi alasan mereka bahwa ekonomi Indonesia bisa menguat kembali di masa mendatang (Dewi \& Budhi, 2017). Namun dengan makin maraknya minimarket yang berdiri dapat secara perlahan mematikan usaha lokal seperti toko kelontong milik perorangan. Namun dalam iklim usaha yang tidak sehat berlaku hukum rimba. Siapa yang kuat dialah yang keluar sebagai pemenang. Mungkin Indonesia belum separah itu, tetapi jika tidak segera dibenahi maka potensi berlaku hukum rimba tinggal selangkah lagi. Pemerintah daerah selaku penguasa wilayah semestinya tahu potensi daerahnya. Berapa daya beli masyarakatnya dan sudah ada berapa ritel yang beroperasi. Selama ini ada 
kecenderungan pemerintah daerah tidak pernah keberatan memberi ijin kepada investor yang hendak membuka gerai ritel (Dewi \& Budhi, 2017). Sasaran utama para investor dalam mengembangkan usahanya yakni pada daerah yang berkembang karena dianggap cukup mudah dalam memasuki pasarnya.

Salah satu daerah berkembang di Jawa Timur yakni Kabupaten Tulungagung yang cukup banyak memiliki populasi penduduk, dan terus meningkat seiring berjalannya waktu. Salah satu daerah/desa Beji Kec. Boyolangu yang merupakan salah satu kawasan padat penduduk, hal ini mempengaruhi pemenuhan kebutuhan yang harus tercukupi setiap harinya. Hal tersebut banyak menjadi incaran para investor untuk memenuhi kebutuhan para penduduk yang semakin meningkat dengan membuka gerai minimarket/minimarket. Sebagian besar masyarakat golongan keatas, lebih banyak memilih berbelanja di minimarket karena dianggap lebih elite. Melihat hal tersebut, eksistensi daripada toko kelontong semakin menurun setiap harinya. Karena dasarnya toko kelontong berdiri sendiri dan berbasis kerakyatan yang mengalami penurunan hingga membuatnya kian hari kian memburuk. Hal ini dikarenakan munculnya minimarket yang dinilai cukup potensial oleh para pebisnis ritel (Wijayanti \& WIRATNO, 2011). Toko-minimarket/ minimarket ini semakin banyak di temui di desa Beji dengan akses yang mudah, mengalahkan eksistensi toko kelontong yang semakin kehilangan pelanggan dan mempengaruhi pendapatan tetapnya.

Berkurangnya penghasilan para pedagang/pemilik toko kelontong ini mempengaruhi kepatuhannya dalam pembayaran Pajak Penghasilan Badan dari penghasilan tokonya. Pajak penghasilan pasal 23 (PPh Pasal 23), yaitu pajak penghasilan yang dikenakan atas penghasilan Wajib Pajak Dalam Negeri atau Bentuk Usaha Tetap yang menerima atau memperoleh penghasilan yang berasal dari modal, penyerahan jasa, atau penyelenggara kegiatan selain yang telah dipotong pajak sebagaimana dimaksud dalam PPh Pasal 21 (Walandouw, 2013).

Tabel 1. Data Kepatuhan Pembayaran Pajak Penghasilan pasal 23 bagi pemilik badan usaha toko kelontong di desa Beji.

\begin{tabular}{|l|l|l|l|l|}
\hline No & Nama Toko & $\begin{array}{l}\text { Membayar } \\
\text { Pajak }\end{array}$ & Cara Membayar & Keterangan \\
\hline
\end{tabular}




\begin{tabular}{|c|c|c|c|c|c|c|}
\hline & & $\mathrm{Ya}$ & Tidak & $\begin{array}{l}\text { Ke } \\
\text { kantor }\end{array}$ & $\begin{array}{l}\text { Di } \\
\text { datangi } \\
\text { petugas }\end{array}$ & \\
\hline 1 & Nayaka & & $\sqrt{ }$ & & & $\begin{array}{l}\text { - Memahami tentang pajak } \\
\text { - Penghasilan tidak tetap }\end{array}$ \\
\hline 2 & Lamitun & & $\sqrt{ }$ & & & $\begin{array}{l}\text { - Kurang memahami pajak } \\
\text { - Penghasilan hanya cukup } \\
\text { untuk kebutuhan sehari-hari }\end{array}$ \\
\hline 3 & Beta & & $\sqrt{ }$ & & & Penghasilan tidak tetap \\
\hline 4 & $\mathrm{Bu}$ As & & $\sqrt{ }$ & & & Penghasilan tidak tetap \\
\hline 5 & Kedai Comel & & $\sqrt{ }$ & & & Penghasilan tidak tetap \\
\hline 6 & Niko & & $\sqrt{ }$ & & & $\begin{array}{l}\text { - Tidak memahami tentang } \\
\text { Pph pasal } 23 \\
\text { - Penghasilan tidak tetap }\end{array}$ \\
\hline 7 & Moro Seneng & & $\sqrt{ }$ & & & $\begin{array}{l}\text { - Tidak memahami tentang } \\
\text { Pph pasal } 23 \\
\text { - Penghasilan tidak tetap }\end{array}$ \\
\hline 8 & Suratun & & $\sqrt{ }$ & & & $\begin{array}{l}\text { - Tidak memahami tentang } \\
\text { Pph pasal } 23 \\
\text { - Penghasilan tidak tetap }\end{array}$ \\
\hline 9 & Murtiah & & $\sqrt{ }$ & & & Toko sepi \\
\hline 10 & $\begin{array}{l}\text { Toko } \mathrm{Bu} \\
\text { Tatik }\end{array}$ & & $\sqrt{ }$ & & & $\begin{array}{l}\text { - Tidak memahami tentang } \\
\text { Pph pasal } 23\end{array}$ \\
\hline
\end{tabular}

Sumber: data primer (wawancara)

Dengan total keseluruhan populasi toko kelontong di Desa Beji sebanyak 21 dan Sample yang digunakan sebanyak 10 Toko. Dimana dari 10 sample yang di dapat, tidak ada satupun toko kelontong yang membayar Pajak Penghasilan Badan. Dengan alasan ratarata pendapatan yang diperoleh tidak tetap disebabkan oleh salah satunya persaingan dengan minimarket. Alasan lain yang mendominasi yakni kurangnya pengetahuan akan Pajak Penghasilan Badan.

Pada Desa Beji sendiri terdapat 2 minimarket yang dapat di akses darimana saja dan ada beberapa minimarket yang lokasinya di sekitar Desa Beji, sedangkan toko kelontong 
hampir tersebar secara merata. Namun dapat dilihat dari data tabel diatas, kepatuhan akan pembayaran pajak masih minim dikarenakan omzet/penghasilan yang tidak menentu dan terbilang cukup kecil membuat pemilik toko kelontong enggan menyisihkan pendapatannya untuk membayar pajak karena dinilai hanya cukup untuk memenuhi kebutuhan sehari-hari keluarganya.

Selain itu, minimnya pengetahuan akan Pajak Penghasilan Badan membuat pemilik toko juga tidak mengetahui secara pasti akan kewajiban pembayaran pajak atas penghasilan tokonya. Dan banyak pemilik toko merasa sudah membayar pajak, namun setelah ditelusuri tenyata pajak yang dibayarkan hanyalah pajak bangunan toko/ Pajak Bumi dan Bangunan. Hal ini seharusnya menjadi perhatian petugas pajak di Kab. Tulungagung untuk melakukan penyuluhan dan sosialisai mengenai Pajak Penghasilan Badan kepada para pemilik toko kelontong agar pengetahuan akan pajak meningkat dan menambah kepatuhan akan pembayaran pajak meningkat. Pemerintah daerah juga seharusnya juga lebih memperhatikan usaha lokal seperti toko kelontong ini dengan cara seperti melakukan pembinaan usaha, peminjaman modal usaha, dan penyuluhan secara rutin terhadap toko kelontong untuk mengetahui tingkat pendapatannya. Dukungan dari pemerintah sendiri dapat memberikan dampak yang besar akan berkembanganya usaha toko kelontong ini hingga secara tidak langsung dapat mempengaruhi perkembangan dan pendapatannya.

Memberian ijin yang mudah terhadap pendirian minimarket juga perlu dipertimbangkan ulang, meskipun banyak dampak baik, juga masih banyak dampak buruk akan banyaknya minimarket ini. Salah satunya banyak mematikan usaha toko kelontong, mempersulit ijin pendirian minimarket juga merupakan salah satu usaha pemerintah daerah dalam pemberian dukungan atas usaha toko kelontong.

Pengaruh munculnya minimarket terhadap toko kelontong, dari hasil penelitian bahwa toko kelontong tidak mampu bersaing dengan minimarket. Sehingga untuk mengatasi ketertinggalan pengembagan mampu melakukan pembiayaan toko kelontong agar mampu bersaing dengan minimarket.

Pajak toko kelontong

Perlakuan pajak untuk toko kelontong akan sama seperti UMKM, yaitu menggunakan skema Pajak Penghasilan (PPh) pasal 23. Dalam artian, besaran pajak 
dihitung dengan cara mengalikan besaran peredaran (omzet) dalam satu tahun pajak. Hanya bisa digunakan bagi toko kelontong yang memiliki omset kurang dari Rp 4.800.000.000 dalam satu tahun pajak. Penghitungan pajak toko kelontong yang memiliki omzet kurang dari Rp 4.800.000.000 dalam satu tahun pajak adalah 0,5\% dari omzet selama satu tahun pajak. Peraturan Pemerintah Nomor 23 Tahun 2018 Tentang Pajak Penghasilan pasal 23 atas Penghasilan dari Usaha yang Diterima.

\section{PENUTUP}

\section{Kesimpulan}

Berdasarkan penelitian, kesimpulan dari hasil penelitian

1. Dengan adanya minimarket memiliki dampak negatif terhadap omset, pendapatan, dan jumlah pelanggan pada usaha toko kelontong. Penurunan omset pada toko kelontong masing-masing sebesar 25\%-50\%. Pendapatan pada toko kelontong sebelum hadirnya minimarket di Desa beji boyolangu cukup stabil, terlihat dengan persaingan antar pedagang toko kelontong saja, dan tidak begitu berpengaruh terhadap pendapatan mereka. Bahkan hal inilah menjadi tolak ukur untuk memenuhi kebutuhan keluarga dari usaha tersebut, terlebih mata pencaharian utama masyarakat di Desa beji adalah membuka usaha kecil seperti pedagang toko kelontong. Selain penurunan omset dan pendapatan, usaha toko kelontong juga mengalami penurunan jumlah pelanggan.

2. Pengetahuan akan Pajak penghasilan badan para pemilik toko kelontong di Desa Beji masih dibilang minim, sehingga membuat kedisiplinan dalam membayarkan pajak masih belum maksimal.

3. Selain itu, pendapatan yang kian menurun membuat para pemilik toko kelontong di Desa Beji menjadi enggan menyisihkan penghasilannya untuk membayar pajak.

\section{Saran}

1. Bagi Pelaku Usaha Kelontong sebaiknya melakukan upaya-upaya untuk mempertahankan eksistensi usahanya, misalnya dengan memperbaiki manajemen usaha, menambah modal usaha dan meningkatkan kualitas pelayan usahanya agar mampu bersaing dengan Minimarket atau minimarket. 
2. Bagi Pemerintah Daerah seharusnya membuat peraturan daerah tentang minimarket agar pendirian minimarket tidak merugikan pihak-pihak lain, seperti usaha mikro, usaha ritel, dan pedagang toko kelontong.

Selain itu, dari peraturan yang telah ada seharusnya diimplementasikan dengan sebaik mungkin agar perekonomian dapat berjalan seimbang. Pemerintah seharusnya berpihak pada pedagang kecil dan berupaya turut melestarika $\mathrm{n}$ usaha mereka.

3. Sistem perpajakan di Indonesia yang menggunakan Self Assement System ini memang memberikan kebebasan bagi wajib pajak orang pribadi untuk menghitung, menetapkan dan melaporkan sendiri pajak penghasilannya, akan tetapi dengan sistem perpajakan seperti ini wajib pajak harus lebih ditingkatkan kesadaran dan pemahaman mengenai pentingnya pemenuhan pajak serta mengenai penghasilan seperti apa yang merupakan objek pajak penghasilan.

\section{DAFTAR PUSTAKA}

Barata, A. A. (2011). Panduan Lengkap Pajak Penghasilan. Visimedia.

Dewi, I. A. S. R., \& Budhi, M. K. S. (2017). Analisis Pendapatan Usaha Warung Tradisional Dengan Munculnya Minimarket Di Kota Denpasar. E-Jurnal EP Unud, 6(12), 23792407.

Halim, A., Bawono, I. R., \& Dara, A. (2014). Perpajakan: Konsep, Aplikasi, Contoh, dan Studi Kasus. Jakarta: Salemba Empat.

Harjo, D. (2013). Perpajakan Indonesia. Jakarta: Mitra Wacana Media.

Hutagaol, J. (2007). Perpajakan isu-isu kontemporer. Yogyakarta: Graha Ilmu.

Nurani, D. P. (2018). Penggaruh Pemeriksaan Pajak Sosialisasi Perpajakan Dan Penerapan E-Filing Terhadap Kepatuhan Wajib Pajak Dan Dampaknya Pada Penerimaan Pajak (Survey Pada Tiga Kantor Pajak Di Wilayah Kota Bandung). Perpustakaan Fakultas Ekonomi dan Bisnis Unpas Bandung.

Ratnawati, E., \& Rachmad Gesah Mukti Prabowo. (2019). MEKANISME PEMUNGUTAN PPN dan PPnBM. 5.

Resmi, S. (2017). Perpajakan teori \& kasus. Salemba Empat. Jakarta.

Spasial, V., Fisik, S., \& Tidak, A. (2013). Analisis dan Pembahasan. 22-41. 
Sudirga, R. S. (2017). Faktor - Faktor Yang Menentukan Peningkatan Bisnis Ritel Di Indonesia. Journal of Business \& Applied Management, 10(02), 138-150. https://doi.org/10.30813/jbam.v10i02.933

Sugiyono, S. (2010). Metode penelitian kuantitatif dan kualitatif dan R\&D. Alfabeta Bandung.

Sunyoto, D. (2015). Manajemen Bisnis Ritel: Teori, Praktik, dan Kasus Ritel. Cetakan Pertama. Yogyakarta: CAPS.

Supranto, J. (2008). Statistik Teori dan Aplikasi Cet. VII. Jakarta: Erlangga.

Sutanto, P. M. (2014). Perpajakan Indonesia (Teori dan Aplikasi). Jakarta: Mitra Wacana Media.

Utami, C. W. (2010). Manajemen Ritel_Strategi dan Implementasi Operasional Bisnis Ritel Modern Di Indonesia. 2010-ISBN: 978-979-061-127-6-Salemba Empat.

Vindasari, R. (2020). Pengaruh Debt To Equity Ratio, Return On Asset, Dan Biaya Operasional Terhadap Pajak Penghasilan Badan Terutang (Studi Kasus Pada Perusahaan Manufaktur Sektor Industri Barang Konsumsi Di Bursa Efek Indonesia Periode 2015-2017). Jurnal Analisa Akuntansi Dan Perpajakan, 3(2).

Walandouw, P. (2013). Analisis Perhitungan Dan Pelaporan Pph Pasal 23 Dan Pph Pasal 25. Jurnal Riset Ekonomi, Manajemen, Bisnis Dan Akuntansi, 1(3), 987-997. https://doi.org/10.35794/emba.v1i3.1908

Wandira, R. (2017). Pengaruh pemeriksaan pajak, sanksi perpajakan, dan self Assessment system terhadap kepatuhan wajib pajak dan Dampaknya terhadap penerimaan pajak (survey pada kantor pelayanan pajak di wilayah kota bandung). Fakultas Ekonomi dan Bisnis Unpas Bandung.

Wijayanti, P., \& WIRATNO, W. (2011). Analisis Pengaruh Perubahan Keuntungan Usaha Warung Tradisional Dengan Munculnya Minimarket (Studi Kasus Di Kecamatan Pedurungan Kota Semarang). Universitas Diponegoro. 